\title{
Expanding Thermal Plasma Chemical Vapour Deposition of ZnO:Al Layers for CIGS Solar Cells
}

\author{
K. Sharma, ${ }^{1}$ B. L. Williams, ${ }^{1}$ A. Mittal, ${ }^{1}$ H. C. M. Knoops, ${ }^{1}$ B. J. Kniknie, ${ }^{2,3}$ N. J. Bakker, ${ }^{3,4}$ \\ W. M. M. Kessels, ${ }^{1,3}$ R. E. I. Schropp, ${ }^{1,3,4}$ and M. Creatore ${ }^{1,3}$ \\ ${ }^{1}$ Department of Applied Physics, Eindhoven University of Technology, P.O. Box 513, 5600 MB Eindhoven, The Netherlands \\ ${ }^{2}$ TNO, P.O. Box 6235, 5600 HE Eindhoven, The Netherlands \\ ${ }^{3}$ Solliance, High Tech Campus 21, 5656 AE Eindhoven, The Netherlands \\ ${ }^{4}$ ECN, High Tech Campus 21, 5656 AE Eindhoven, The Netherlands
}

Correspondence should be addressed to K. Sharma; k.sharma@tue.nl

Received 24 April 2014; Accepted 7 June 2014; Published 6 July 2014

Academic Editor: Serap Gunes

Copyright (C) $2014 \mathrm{~K}$. Sharma et al. This is an open access article distributed under the Creative Commons Attribution License, which permits unrestricted use, distribution, and reproduction in any medium, provided the original work is properly cited.

\begin{abstract}
Aluminium-doped zinc oxide ( $\mathrm{ZnO}: \mathrm{Al}$ ) grown by expanding thermal plasma chemical vapour deposition (ETP-CVD) has demonstrated excellent electrical and optical properties, which make it an attractive candidate as a transparent conductive oxide for photovoltaic applications. However, when depositing ZnO:Al on CIGS solar cell stacks, one should be aware that high substrate temperature processing (i.e., $>200^{\circ} \mathrm{C}$ ) can damage the crucial underlying layers/interfaces (such as $\mathrm{CIGS} / \mathrm{CdS}$ and $\mathrm{CdS} / \mathrm{i}-\mathrm{ZnO}$ ). In this paper, the potential of adopting ETP-CVD ZnO:Al in CIGS solar cells is assessed: the effect of substrate temperature during film deposition on both the electrical properties of the $\mathrm{ZnO}: \mathrm{Al}$ and the eventual performance of the CIGS solar cells was investigated. For $\mathrm{ZnO}$ :Al films grown using the high thermal budget (HTB) condition, lower resistivities, $\rho$, were achievable $\left(\sim 5 \times 10^{-4} \Omega \cdot \mathrm{cm}\right)$ than those grown using the low thermal budget (LTB) conditions $\left(\sim 2 \times 10^{-3} \Omega \cdot \mathrm{cm}\right)$, whereas higher CIGS conversion efficiencies were obtained for the LTB condition (up to 10.9\%) than for the HTB condition (up to 9.0\%). Whereas such temperature-dependence of CIGS device parameters has previously been linked with chemical migration between individual layers, we demonstrate that in this case it is primarily attributed to the prevalence of shunt currents.
\end{abstract}

\section{Introduction}

Recently, very high conversion efficiencies of up to $20.8 \%$ have been demonstrated for CIGS solar cells [1]. The CIGS absorber layer has a direct band gap, and it is tunable from $\sim 1.02 \mathrm{eV}$ for copper indium selenide $\left(\mathrm{CuInSe}_{2}\right)$ to $\sim$ $1.65 \mathrm{eV}$ for copper gallium selenide $\left(\mathrm{CuGaSe}_{2}\right)$ [2-4]. The typical structure for a CIGS solar cell is $\mathrm{ZnO}: \mathrm{Al} / \mathrm{i}-\mathrm{ZnO} / \mathrm{CdS} /$ $\mathrm{CIGS} / \mathrm{Mo} /$ glass $[3,5]$. Undoped $\mathrm{ZnO}(\mathrm{i}-\mathrm{ZnO})$ with a typical thickness of $\sim 50 \mathrm{~nm}$, situated between the CdS buffer layer and the transparent front contact, is included to provide local series resistance to limit the detrimental effect of electrical inhomogeneities, for example, short circuits [6-8]. Al-doped $\mathrm{ZnO}$ ( $\mathrm{ZnO}: \mathrm{Al})$ on top of the $\mathrm{i}-\mathrm{ZnO}$ layer acts as the front contact: it should be conductive enough (resistivity should generally be in the range of $10^{-4} \Omega \cdot \mathrm{cm}$ ) to provide transport to generated charge carriers and also should be optically transparent $(>80 \%)$ in the active range of the CIGS device $(1-3 \mathrm{eV})$. Note that the upper limit of the active range is dependent on the band gap of the CIGS layer, that is, from $750 \mathrm{~nm}$ to $1200 \mathrm{~nm}$ (some state-of-the-art devices [9] have high quantum efficiency throughout the range $350-1100 \mathrm{~nm}$ ) and so the optical requirements may vary $[7,8]$.

Owing to the optical and electrical requirements described above, the deposition of $\mathrm{ZnO}: \mathrm{Al}$ on CIGS solar cells is a critical step in cell development, not the least because the process should be compatible with (i.e., induce no damage) the underlying stack. Sputtering has been commonly used to deposit $\mathrm{ZnO}: \mathrm{Al}$ thin films, and CIGS solar cells with sputtered $\mathrm{ZnO}: \mathrm{Al}$ have shown efficiencies as high as $20 \%$ [10]. An alternative to sputtering is the expanding thermal plasma chemical vapour deposition (ETP-CVD) technique. ETP-CVD has shown the capability to grow high-quality $\mathrm{ZnO}: \mathrm{Al}$ (resistivity $\sim 10^{-4} \Omega \cdot \mathrm{cm}$ and 
TABLE 1: The experimental parameters used to deposit ZnO:Al layers at low thermal budget (LTB) and high thermal budget (HTB) conditions.

\begin{tabular}{lccccccccc}
\hline Condition & $\Phi_{\mathrm{DEZ}}(\mathrm{g} / \mathrm{h})$ & $\Phi_{\mathrm{TMA}}(\mathrm{g} / \mathrm{h})$ & $\Phi_{\mathrm{Ar}}(\mathrm{s} \operatorname{lm})$ & $\Phi_{\mathrm{O} 2}(\mathrm{slm})$ & $p(\mathrm{mbar})$ & $\begin{array}{c}\text { Temp. } \\
\text { set-point }\left({ }^{\circ} \mathrm{C}\right)\end{array}$ & $\begin{array}{c}\text { He flow } \\
(\mathrm{min})\end{array}$ & $\begin{array}{c}\text { Time } \\
T_{f}\left({ }^{\circ} \mathrm{C}\right)\end{array}$ \\
\hline LTB & 4.5 & 0.6 & 1.5 & 100 & 2 & 100 & On & $3.3-13.3$ & $140-290$ \\
HTB & 4.5 & 0.6 & 1 & 100 & 2 & 100 & Off & $6.0-30.4$ & $158-392$ \\
\hline
\end{tabular}

transparency $>85 \%$ ) at temperatures above $200^{\circ} \mathrm{C}$, with high growth rates $(1 \mathrm{~nm} / \mathrm{s})$, and accompanied by a negligible ion bombardment $(<2 \mathrm{eV})$ at the substrate $[11,12]$. ETP-CVD has already been employed at industrial scales for the deposition of $\mathrm{SiN}_{x}$ antireflection layers and passivation layers [13] and $\mathrm{ZnO}: \mathrm{Al}$ front contacts for a-Si:H solar cells [14].

In this work, the feasibility of ETP-CVD grown $\mathrm{ZnO}: \mathrm{Al}$ as a front contact in CIGS is investigated. Since CIGS solar cell efficiencies have elsewhere been shown to degrade when devices are subject to high temperatures [15], particular interest is paid to the effect of $\mathrm{ZnO}$ : $\mathrm{Al}$ deposition conditions on the solar cell performance parameters. Low resistivities were achieved for ETP-CVD grown $\mathrm{ZnO}: \mathrm{Al}$, that is, as low as $6 \cdot 10^{-4} \mathrm{ohm} \cdot \mathrm{cm}$ for a film thickness of $300 \mathrm{~nm}$, but the efficiency of the finished CIGS devices was seen to be particularly sensitive to the substrate temperature reached during the ETP-CVD process. Whereas such temperaturedependence has been linked in literature [15] to thermally induced chemical migration between individual layers, we demonstrate that in our case it is primarily linked to the presence of macroscale defects, inducing the prevalence of shunt currents upon thermal exposure. Shunt-causing pinhole defects were intrinsically present in the CIGS layer, and their detrimental impact was exacerbated by high thermal budget $\mathrm{ZnO}: \mathrm{Al}$ deposition conditions, thus demonstrating that the processing restrictions for the front contact are highly dependent on the quality of the underlying films.

\section{Experimental}

In this work, $\mathrm{ZnO}$ :Al films were deposited by means of a remote plasma-enhanced chemical vapour deposition process, that is, the ETP-CVD technique $[16,17]$. In the cascaded arc plasma source, a DC discharge is generated in Ar gas at subatmospheric pressure between three cathode tips and an anode plate. The discharge is current controlled by a DC power supply and the power dissipated is typically within the $2-5 \mathrm{~kW}$ range $[18,19]$. The plasma in the arc has an electron density of $10^{22} \mathrm{~m}^{-3}$ and an electron temperature of $\sim 1 \mathrm{eV}$. The plasma emanates from the arc source (which is typically at 200-600 mbar) through a nozzle and expands into the deposition chamber which is at a pressure of 2 mbar [20]. Due to the pressure difference, the plasma expands supersonically and dissociates gaseous precursors that are injected upstream in the expanding plasma. The precursor gases used were diethylzinc (DEZ) and trimethylaluminium (TMA). These liquid precursors were supplied to the reactor chamber utilizing Bronkhorst Hi-Tec mass flow controllers for vapour flow and liquid containing bubblers. The vapour based dosing system was used to dose the premixed precursors (TMA and
DEZ) into the reactor. $\mathrm{O}_{2}$ was injected into the reactor via an injection ring placed at $6.5 \mathrm{~cm}$ from the plasma source exit, whereas the precursors were injected in the background of the plasma. The injected precursors ionize via charge exchange reactions with the Ar ions in the plasma before recombination reactions with electrons dissociate the precursor molecular ions into the depositing radicals $[21,22]$.

Three $2.5 \mathrm{~cm} \times 2.5 \mathrm{~cm}$ substrates were used during each deposition: one CIGS solar cell on glass, for device characterisation, and two $\mathrm{SiO}_{2}(450 \mathrm{~nm}) / c$-Si wafers, used as reference samples to characterise the optoelectronic properties of the $\mathrm{ZnO}: \mathrm{Al}$ films. In the reactor, the substrate holder was heated to $100^{\circ} \mathrm{C}$ for 15 minutes prior to deposition. The active plasma mixture is transported towards the substrate at a velocity in the range $500-1000 \mathrm{~m} / \mathrm{s}[18,19]$. Such high convective flux is responsible for an increase in the substrate temperature during deposition. The extent of this additional heating is greater when higher Ar flows and/or arc currents are used since a larger density of reactive species reach the substrate. The heating effect is enhanced by a longer deposition time.

The $\mathrm{ZnO}$ :Al deposition parameters of the two conditions used here are shown in Table 1. All parameters were kept constant except for the Ar flow rate. For both conditions, preliminary growth runs were made to check the final temperature $\left(T_{f}\right)$ reached following a range of deposition times, using temperature-sensitive stickers mounted on the samples (Table 1 includes these data). In both cases, the temperature increased linearly with time from the set-point of $100^{\circ} \mathrm{C}$. Since higher temperatures $\left(T_{f}=158-392^{\circ} \mathrm{C}\right)$ were achieved when using $1 \mathrm{slm} \mathrm{Ar}$ in the absence of He back flow, this is denoted by the high thermal budget (HTB) condition, whereas the use of $1.5 \mathrm{slm}$ Ar, combined with He back flow, is defined as the low thermal budget (LTB) condition $\left(T_{f}=\right.$ $140-290^{\circ} \mathrm{C}$ ). Note that the thermal budget was predominantly determined by the deposition time: because the HTB condition yielded much slower growth rates $(0.35-0.38 \mathrm{~nm} / \mathrm{s})$ than the LTB condition $(0.9-1.0 \mathrm{~nm} / \mathrm{s})$, longer deposition times were necessary in the former case to accumulate comparable film thicknesses.

The $\mathrm{ZnO}: \mathrm{Al} / \mathrm{i}-\mathrm{ZnO} / \mathrm{CdS} / \mathrm{CIGS} / \mathrm{Mo} /$ glass device fabrication process is summarised in Table 2. The table includes the deposition techniques used for each of the individual films and the film thicknesses. The maximum temperature reached during the entire process was $550^{\circ} \mathrm{C}$ (which occurs during coevaporation of the CIGS layer). For contacting, $\mathrm{Au}$ finger contacts were deposited onto the $\mathrm{ZnO}$ :Al by thermal evaporation, and individual cells $(5 \times 10 \mathrm{~mm})$ were defined by scribing. For comparison, a reference cell was made whereby RF sputtering was used (rather than ETP-CVD) to deposit the $\mathrm{ZnO}: \mathrm{Al}$ front contact, and in this case the substrate reached a maximum temperature of only $60^{\circ} \mathrm{C}$. 


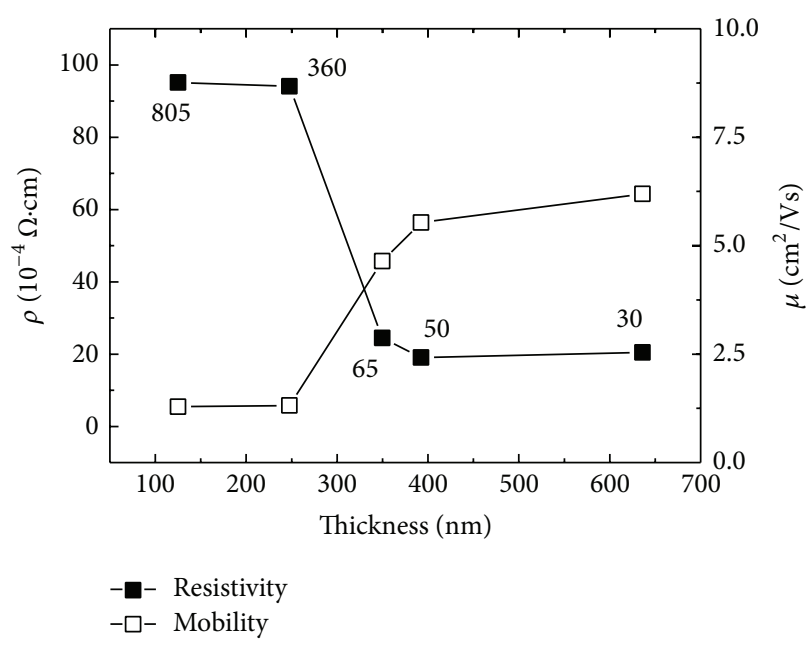

(a)

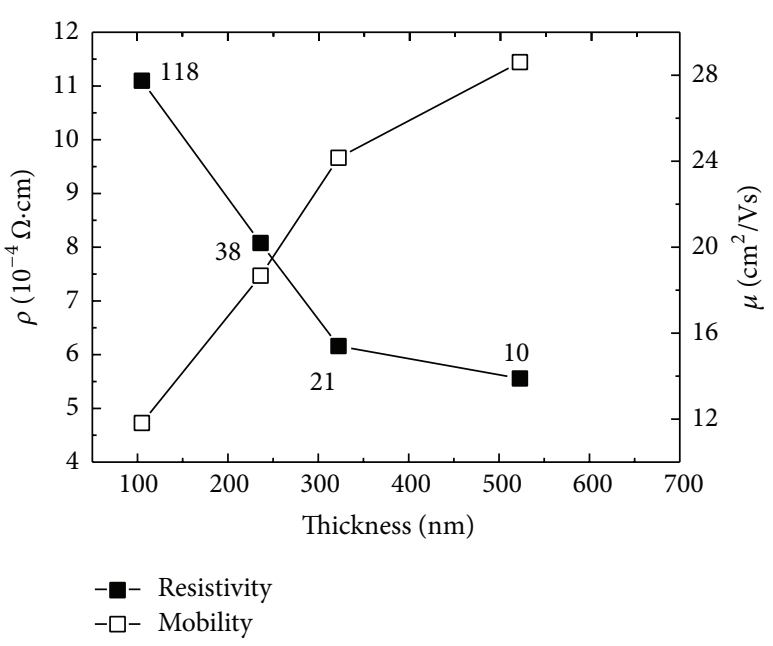

(b)

Figure 1: Variation of resistivity, $\rho$, and mobility, $\mu$, as a function of ETP-CVD ZnO:Al layer thickness for (a) low thermal budget and (b) high thermal budget conditions. Note that resistivity of the sputtered $\mathrm{ZnO}$ :Al films $\left(650 \mathrm{~nm}\right.$ thick, used for the reference cell) was $\sim 8 \times 10^{-4} \Omega \cdot \mathrm{cm}$. Sheet resistances $(\Omega / \square)$ are indicated next to the resistivity data points.

TABLE 2: Structure of CIGS solar cell, with the deposition procedures and film thicknesses included for each layer.

\begin{tabular}{lcl}
\hline Layer & Thickness & Deposition method \\
\hline ZnO:Al & $100-800 \mathrm{~nm}$ & ETP-CVD (reference: RF sputtering) \\
i-ZnO & $50 \mathrm{~nm}$ & RF sputtering \\
$\mathrm{CdS}$ & $35 \mathrm{~nm}$ & Chemical bath deposition \\
$\mathrm{CIGS}$ & $2 \mu \mathrm{m}$ & Coevaporation \\
$\begin{array}{l}\text { Mo } \\
\text { Soda-lime } \\
\text { glass }\end{array}$ & $300-400 \mathrm{~nm}$ & Sputtering \\
\hline
\end{tabular}

Several diagnostics were used to analyse the material properties of $\mathrm{ZnO}: \mathrm{Al}$ films and the CIGS solar cell characteristics. Carrier concentrations and film thicknesses of $\mathrm{ZnO}: \mathrm{Al}$ were computed upon fitting spectroscopic ellipsometry data with an optical mode-this method is described in detail in [23]. Resistivities were measured using the four-point-probe technique, and electrical mobilities were calculated from these resistivity values and the (optically determined) carrier concentrations. Chemical compositions were determined by $\mathrm{X}$-ray photoelectron spectroscopy (XPS). Current densityvoltage $(J-V)$ data was recorded under AM1.5 conditions (at $25^{\circ} \mathrm{C}$ ) and also in the dark. Note that the quoted solar cell performance parameters (Figure 2) are for the best individual cells measured from each sample (each sample typically had 6-9 cells). Scanning electron microscopy was employed for imaging the samples, with micrographs being acquired in secondary electron mode. Elemental depth profiles of CIGS cells were measured by time-of-flight secondary ion mass spectrometry (TOF-SIMS), using a TOF-SIMS IV instrument operated in positive mode with $2 \mathrm{keV} \mathrm{Cs}{ }^{+}$ions for sputtering.

\section{Results and Discussion}

3.1. Characterization of $\mathrm{ZnO}: \mathrm{Al}$ Films. Figure 1 shows the variation of resistivity and mobility as a function of film thickness for both conditions. The LTB condition results in films with a minimum resistivity of $2 \times 10^{-3} \Omega \cdot \mathrm{cm}$ and a maximum mobility of $6 \mathrm{~cm}^{2} / \mathrm{Vs}$ (for a film thickness of $\sim$ $800 \mathrm{~nm}$ ). On the other hand, the $\mathrm{ZnO}: \mathrm{Al}$ films deposited at HTB had a minimum resistivity of $5 \times 10^{-4} \Omega \cdot \mathrm{cm}$ and a mobility of $28 \mathrm{~cm}^{2} / \mathrm{Vs}$ (for a film thickness of $\sim 500 \mathrm{~nm}$ ). It is worth mentioning that the thinnest sample of the HTB condition had higher mobility and lower resistivity than the thickest sample of the LTB condition. Note that the resistivity of the sputtered $\mathrm{ZnO}: \mathrm{Al}$ film ( $400 \mathrm{~nm}$ thick) that was used for the reference cell was $\sim 8 \times 10^{-4} \Omega \cdot \mathrm{cm}$, that is, higher than the minimum achieved for ETP-CVD $\mathrm{ZnO}: \mathrm{Al}$ films.

For both ETP-CVD conditions, XPS analysis confirmed that the composition of the $\mathrm{ZnO}$ : Al films was not significantly influenced by the choice of deposition conditions. The O/Zn ratio was $1.09 \pm 0.10$ and $0.98 \pm 0.09$ in LTB and HTB conditions, respectively, and the $\mathrm{Al}$ content was $\sim 2$ at. \% in both cases. The carrier concentrations were similar- $(5.5$ $\pm 0.5) \times 10^{20} \mathrm{~cm}^{-3}$ for LTB and $(4.5 \pm 0.5) \times 10^{20} \mathrm{~cm}^{-3}$ for HTB - and so the lower resistivity values achieved for HTB conditions can entirely be attributed to the higher mobility. As discussed in depth in our previous publications [11, 12], the high mobilities achieved at HTB are the result of the development of the grain size with film thickness; that is, grain boundary scattering is progressively reduced upon grain size development $[11,12]$. Therefore, it is inferred that the lower mobilities achieved using LTB conditions are a result of reduced grain size development. With regards to optical transmittance, note that in our previous work we 

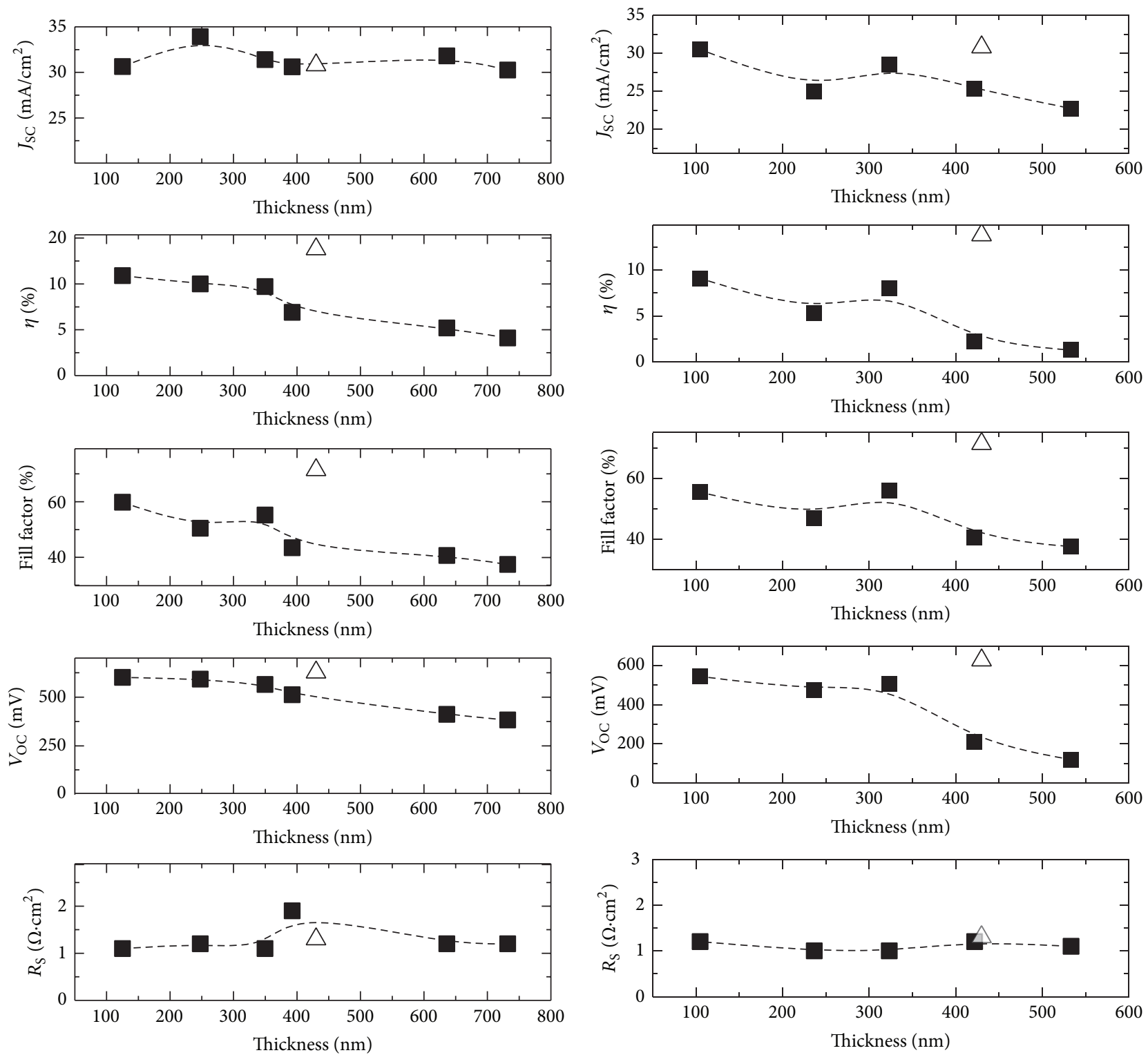

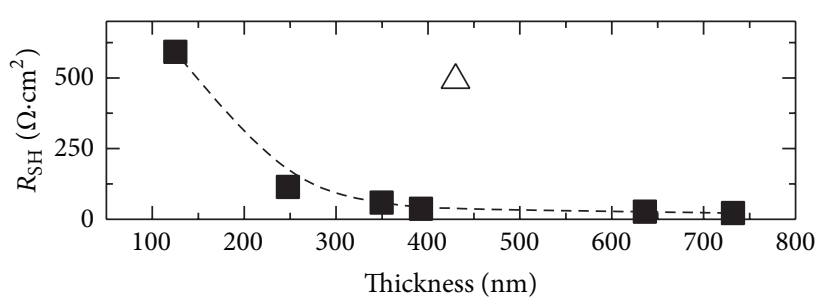

(a)

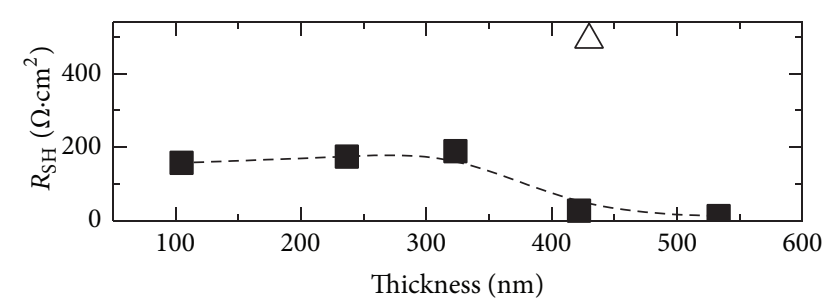

(b)

Figure 2: Variation of short circuit density $\left(J_{\mathrm{sc}}\right)$, fill factor $(\mathrm{FF})$, conversion efficiency $(\eta)$, open circuit voltage $\left(V_{\mathrm{oc}}\right)$, series resistance $\left(R_{S}\right)$, and shunt resistance $\left(R_{\mathrm{SH}}\right)$ as a function of $\mathrm{ZnO}$ :Al layer thickness for (a) low thermal budget and (b) high thermal budget conditions. Solar cell parameters of the reference cell are indicated by the open triangles. Dashed lines are used as a guide to the eye.

demonstrated that $\mathrm{ZnO}$ :Al films, grown by ETP-CVD using similar conditions as here and having similar carrier concentrations $\left(\sim 5 \times 10^{20} \mathrm{~cm}^{-3}\right)$, have transmittances $>80 \%$ in the range $350-900 \mathrm{~nm}$ and $60-80 \%$ in the range $900-1100 \mathrm{~nm}$ [20].
3.2. CIGS Solar Cell Characterisation. Figure 2 shows the solar cell parameters (short circuit current density $\left(J_{\mathrm{sc}}\right)$, fill factor (FF), open circuit voltage $\left(V_{o c}\right)$, conversion efficiency $(\eta)$, shunt resistance $\left(R_{\mathrm{SH}}\right)$, and series resistances $\left.\left(R_{\mathrm{S}}\right)\right)$ as a function of $\mathrm{ZnO}$ :Al layer thickness for both conditions. $R_{\mathrm{SH}}$ 
and $R_{S}$ were calculated from the gradients of the $J-V$ curves at short circuit and open circuit conditions, respectively. A $V_{\text {oc }}$ of $600 \mathrm{mV}$ and conversion efficiency of $10.9 \%$ was achieved with a thin $125 \mathrm{~nm} \mathrm{ZnO:Al} \mathrm{layer} \mathrm{deposited} \mathrm{at} \mathrm{LTB} \mathrm{conditions.}$ With increasing $\mathrm{ZnO}$ :Al layer thickness (and hence, increasing deposition time) a decrease in $V_{\text {oc }}$, FF and, $\eta$ (Figure 2(a)) was observed. For instance, for $\sim 730 \mathrm{~nm} \mathrm{ZnO:Al}$, we found that $\eta=4.1 \%, V_{\mathrm{oc}}=383 \mathrm{mV}$, and $\mathrm{FF}=37.5 \%$. No such systematic degradation of $J_{\mathrm{sc}}$ was evident. A similar trend was observed for $\mathrm{ZnO}$ :Al films deposited at HTB conditions: the highest efficiency achieved was $9 \%$ for $\sim 100 \mathrm{~nm} \mathrm{ZnO:Al}$ and the lowest efficiency was $1.3 \%$ for $\sim 530 \mathrm{~nm} \mathrm{ZnO:Al}$. In this case, $V_{\text {oc }}$ decreased to very low values $(\sim 100 \mathrm{mV})$, and a gradual decrease in $J_{\mathrm{sc}}$ with increasing $\mathrm{ZnO}$ : Al thickness was also seen (from $30 \mathrm{~mA} \cdot \mathrm{cm}^{-2}$ to $24 \mathrm{~mA} \cdot \mathrm{cm}^{-2}$ ). Since the thicker $\mathrm{ZnO}$ :Al films actually have a lower sheet resistance than the thinner films (values included in Figure 1), the performance loss with increasing $\mathrm{ZnO}$ :Al thickness suggests that the higher thermal budget that is associated with longer deposition times causes degradation of the underlying solar cell stack (this is discussed in detail below). This is consistent with the observation that a lower peak efficiency and a more pronounced degradation with deposition time were obtained for the HTB conditions than for the LTB conditions. Furthermore, the reference sample, for which the $\mathrm{ZnO}: \mathrm{Al}$ was sputter-deposited at a lower temperature, had higher $\eta$ $(13.8 \%)$ and $V_{\text {oc }}(627 \mathrm{mV})$ than all devices with ETP-CVD grown $\mathrm{ZnO}$ :Al. The lower efficiencies obtained from the ETP-CVD process are not considered to be related to the electrical quality of the films given that the series resistance of all devices was comparable to that of the reference cell. However, given that the resistivities of the $\mathrm{ZnO}: \mathrm{Al}$ layers on the best ETP-CVD completed cells were higher than those of the sputtered $\mathrm{ZnO}$ :Al layers on the reference cell, this comparability is to be attributed to a "levelling" effect provided by the Au finger contacts. On the contrary, the shunt resistance was highly dependent on $\mathrm{ZnO}$ : Al deposition conditions, and this is now discussed in more detail.

Figure 3 shows the $J-V$ curves of the best and worst samples from both LTB and HTB conditions. It is clear from the increasing gradient at $V=0$ that $R_{\mathrm{sh}}$ is lower following HTB deposition of ZnO:Al. Indeed, as shown in Figure 2, $R_{\mathrm{sh}}$ decreases with increasing $\mathrm{ZnO}$ :Al thickness to very low values in both LTB and HTB cases $\left(12 \Omega \cdot \mathrm{cm}^{2}\right.$ for the lowest efficiency device, $\eta=1.3 \%$ ), alongside the decrease in all other performance parameters. Typically, low $R_{\mathrm{sh}}$ values are only detrimental to FF, but, for particularly low $R_{\mathrm{sh}}$, both $V_{\mathrm{oc}}$ and $J_{\text {sc }}$ will also be significantly affected (in the case of $J_{\mathrm{sc}}$, this is only true when $R_{S}$ is nonnegligible, i.e., $\geq 1 \Omega \cdot \mathrm{cm}^{2}$ ). Therefore, the degradation of $R_{\mathrm{sh}}$ could be sufficient to account for the degradation of all other parameters.

Interestingly, in the literature, thermally induced degradation of CIGS solar cells has been attributed primarily to $V_{\mathrm{oc}}$ loss upon excessive $\mathrm{Cd}$ diffusion from the $\mathrm{CdS}$ window layer into the CIGS absorber. In this scenario, Cd diffusion causes the formation of a buried junction towards the back contact and a lower built-in potential (which defines the upper limit to $V_{\mathrm{oc}}$ ) [15]. To investigate whether significant elemental

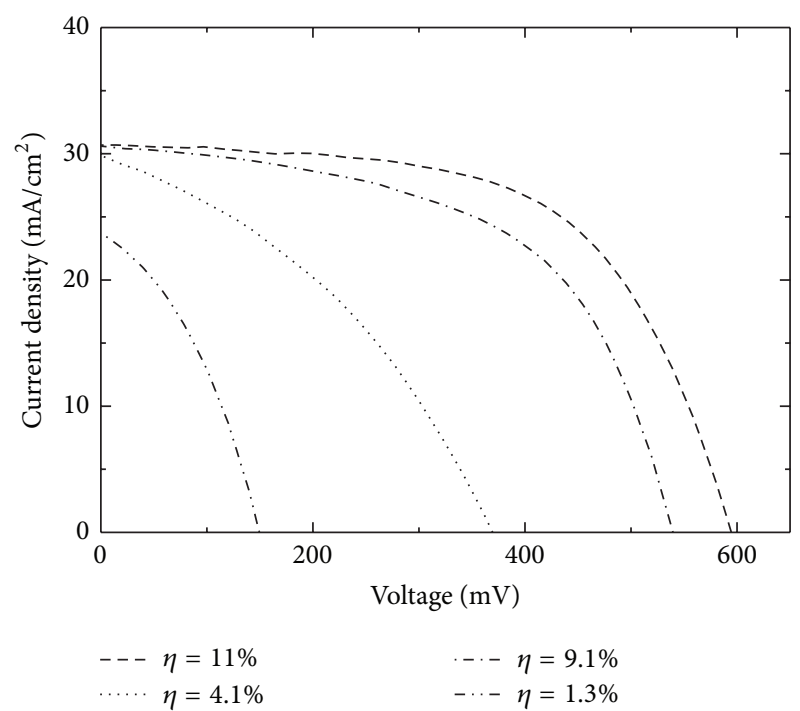

FIgUre 3: $J-V$ curves of four CIGS samples. Cells with $11 \%$ and $4.1 \%$ conversion efficiency for the thinner and thickest $\mathrm{ZnO}: \mathrm{Al}$ were generated using low thermal budget $\mathrm{ZnO}: \mathrm{Al}$ deposition conditions, whilst the $9.1 \%$ and $1.3 \%$ cells also for the thinner and thickest were developed using high thermal budget conditions.

migration occurred also in our devices, TOF-SIMS depth profiles were performed on both the 10.9\% LTB device and the 1.3\% HTB device, and this data is shown in Figure 4. No evidence of significant (or, indeed, comparable to literature [15]) Cd diffusion into the CIGS layer was detected in the case of the HTB conditions. In comparison, Kijima and Nakada [15], who exposed CIGS devices to postgrowth annealing at higher temperatures of up to $400^{\circ} \mathrm{C}$, showed that the $\mathrm{Cd}$ counts in the top $200 \mathrm{~nm}$ of the CIGS layer increased by an order of magnitude following annealing.

Looking for alternative paths to the degradation of $R_{\mathrm{sh}}$, it is interesting to notice that the parameters of the reference cell have also a low $R_{\mathrm{sh}}$, when compared to state-of-theart devices $[1,24]$. We presently attribute this to macroscale defects that were found in the devices, as highlighted by the SEM analysis in Figure 5. In detail, the image in Figure 5(a) was taken after CIGS deposition and shows a large particle $\left(>10 \mu \mathrm{m}\right.$ in size and confirmed to be $\mathrm{CuSe}_{x}$ by energy dispersive $\mathrm{X}$-ray analysis) that formed during the three-stage evaporation of CIGS. This particle evidently forms at the expense of the film in the surrounding area, thus creating a crater (or pinhole) in the CIGS film. Figure 5(b) shows a similar structure following $\mathrm{ZnO}: \mathrm{Al} / \mathrm{i}-\mathrm{ZnO} / \mathrm{CdS}$ deposition; the $\mathrm{CuSe}_{x}$ particle has been removed, leaving a pinhole in the absorber layer, into which the window layers are deposited. These images are representative of a number of similar features found in all devices (approximately 1-5 per cell), which were an intrinsic feature of the CIGS layer, regardless of which $\mathrm{ZnO}$ :Al process is used. We therefore hypothesize that the cell performance degradation upon increased thermal budget exposure is driven by shunting phenomena involving the abovementioned defects.

In order to gain more insight into the shunting phenomena, dark $J-V$ curves were measured for samples with varying 


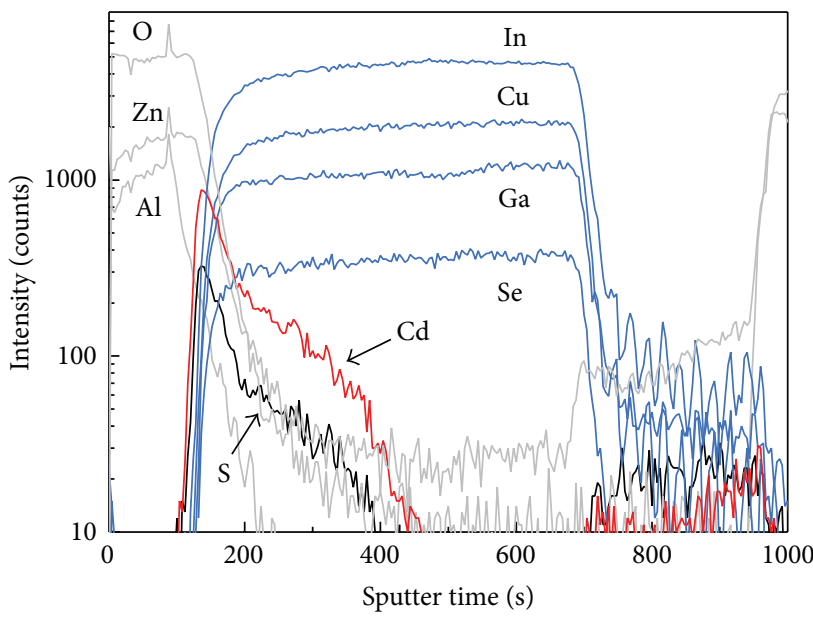

(a)

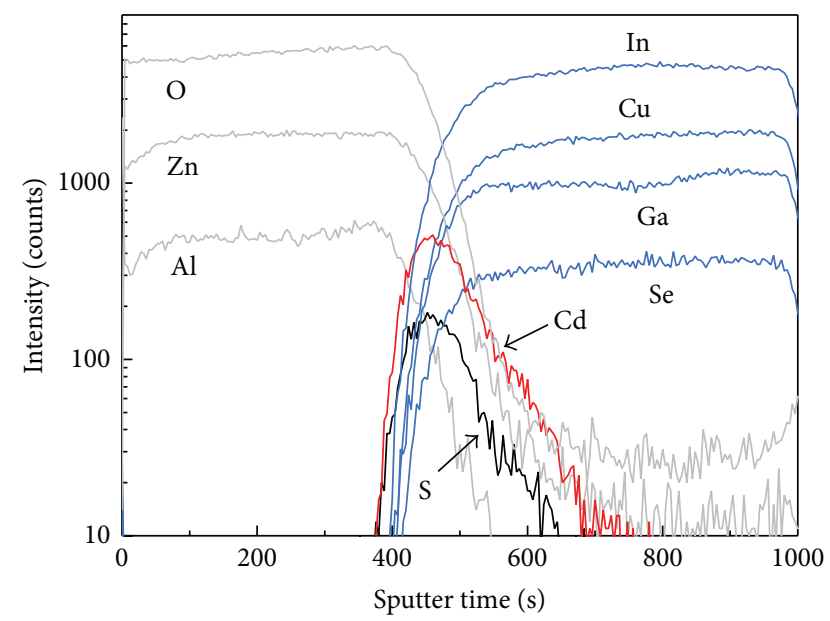

(b)

FIGURE 4: TOF-SIMS depth profiles of $\mathrm{ZnO}$ :Al/CdS/CIGS region in (a) a low thermal budget grown device with $\eta=10.9 \%$ and (b) a high thermal budget device with $\eta=1.3 \%$. Note that the onset of the constituent elements within CdS and CIGS layers are shifted along the $x$-axis in (b) since the device had a thicker $\mathrm{ZnO}$ :Al front contact.

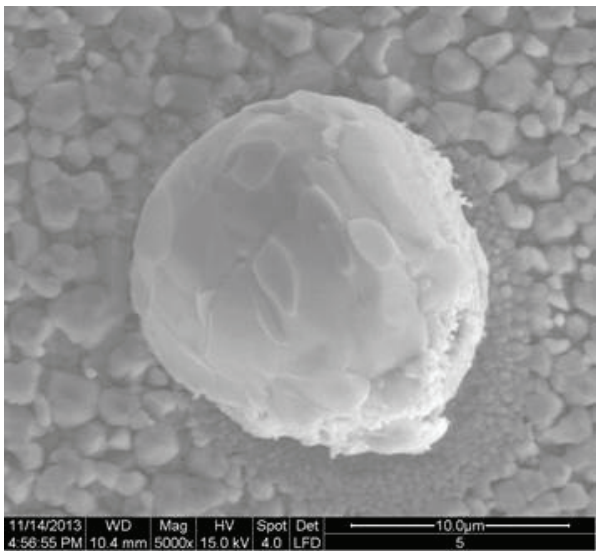

(a)

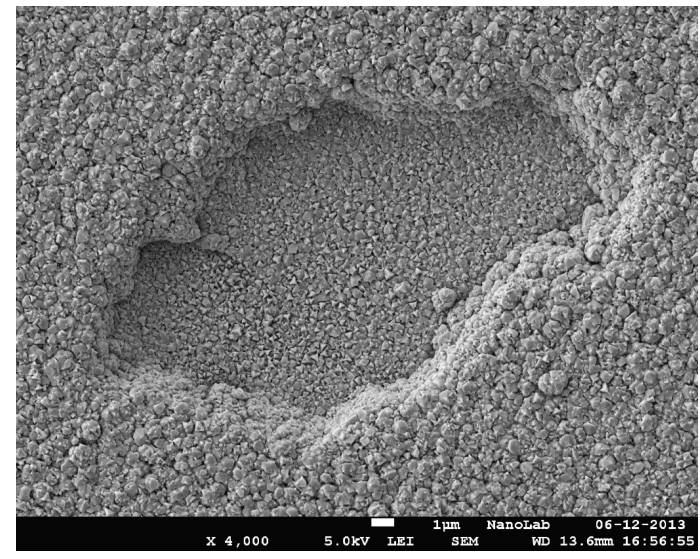

(b)

FIGURE 5: Secondary-electron SEM images of shunt-causing defects. (a) Following CIGS deposition, numerous CuSe $\mathrm{e}_{x}$ particles were found within crater-like defects. (b) Following $\mathrm{ZnO}: \mathrm{Al} / \mathrm{i}-\mathrm{ZnO} / \mathrm{CdS}$ deposition, the $\mathrm{CuSe}_{x}$ particles are no longer seen, but numerous craters remain.

ZnO:Al thicknesses, both for LTB and HTB conditions (Figures 6(a) and 6(b), resp.). The response from the reference sample (with sputtered $\mathrm{ZnO}: \mathrm{Al}$ ) is included in each case and this is described first since it serves as the baseline device with the highest efficiency. As indicated in the figure, there are two distinct regions in the reference $J-V$ data. Region 1: in reverse bias and low forward bias $(<0.5 \mathrm{~V})$, the curve is flattened out and is mostly symmetric about the zero bias axis. Region 2 : at high forward bias $(>0.5 \mathrm{~V})$, the gradient increases and the device exhibits the expected diode-like behaviour. This tworegion behaviour is universally observed for a number of different solar cell technologies that are affected by shunting [25]. As the dark current, $J_{D}$, is commonly expressed by the modified Shockley diode equation,

$$
J_{D}=J_{0}\left(\exp \left(\frac{q\left(V-J_{D} R_{S}\right)}{n k T}\right)-1\right)+\frac{V-J_{D} R_{S}}{R_{\mathrm{SH}}}
$$

where $J_{0}$ is the reverse saturation current, $n$ is the diode ideality factor, $k$ is Boltzmann's constant, and $T$ is the temperature, it is clear that region 1 is dominated by the second term, the leakage current, and region 2 by the first term, the diode current (the rollover at high forward bias is typically attributed to series resistance). The LTB sample with a $\mathrm{ZnO}: \mathrm{Al}$ thickness of $\sim 250 \mathrm{~nm}(\eta=10.2 \%)$ has a similar shaped curve to that of the reference but has comparatively higher current in region 1 and lower current in region 2, indicating that the leakage current term is more dominant. With increasing $\mathrm{ZnO}: \mathrm{Al}$ thickness (and hence increasing thermal budget), the curves become increasingly flattened out (as shown by the sample with a $\mathrm{ZnO}: \mathrm{Al}$ thickness of $\sim 730 \mathrm{~nm}$ and $\eta=4.1 \%$ ), indicating that they are increasingly dominated by the leakage current. The increases in current in the leakage current region with increased $\mathrm{ZnO}: \mathrm{Al}$ thickness are indicated by the bold arrow in the figure. The same 


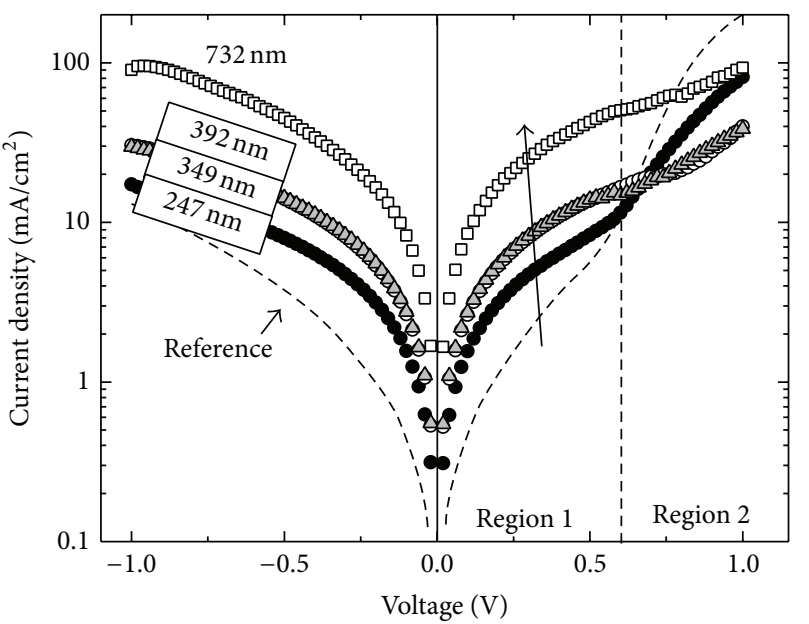

(a)

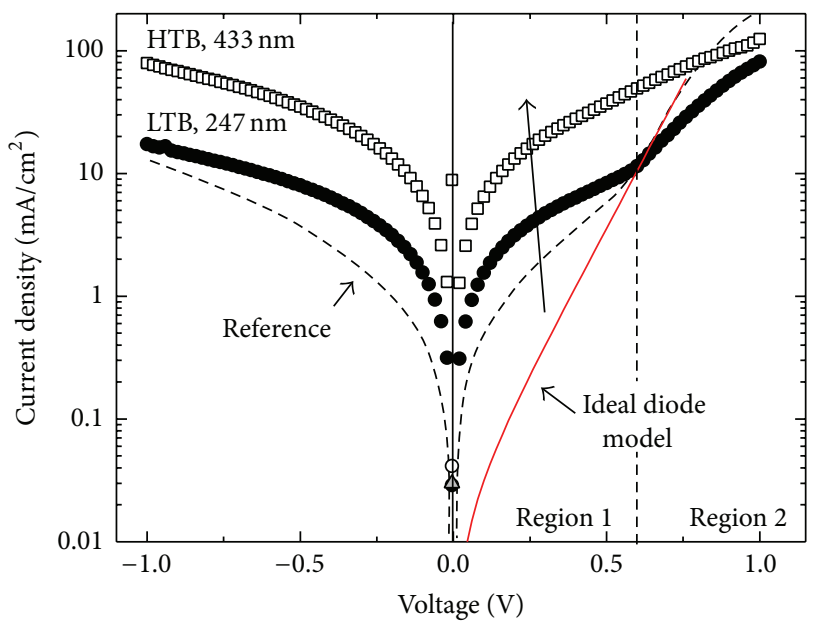

(c)

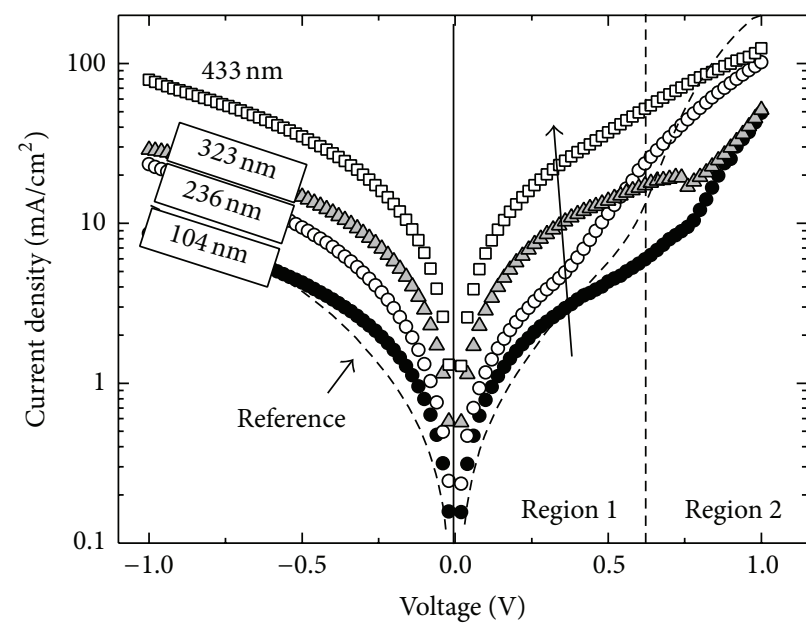

(b)

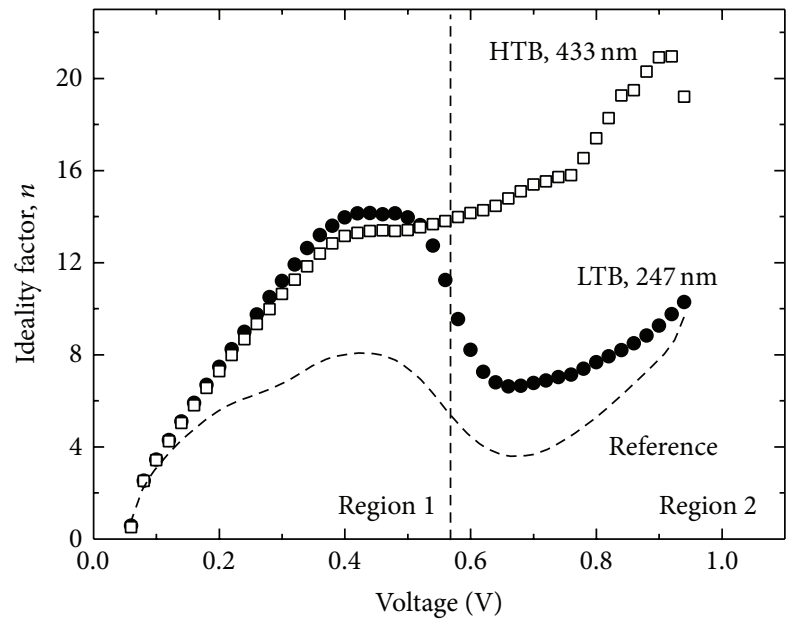

(d)

FIgure 6: Dark $J-V$ curves of CIGS samples with the ZnO:Al layer deposited under (a) low thermal budget and (b) high thermal budget conditions for different $\mathrm{ZnO}$ :Al thicknesses in each case (thickness values are indicated on each curve). The response from the reference cell is also included. (c) A comparison of the dark $J-V$ response for low thermal budget $\left(d_{\mathrm{AzO}}=247 \mathrm{~nm}\right)$, high thermal budget $\left(d_{\mathrm{AzO}}=433 \mathrm{~nm}\right)$, and reference samples. Bold arrows in (a)-(c) indicate the increased leakage current with increased thermal budget. (d) Ideality factor as a function of voltage, calculated for the curves shown in (c) using the ideal diode equation.

trend is seen for the HTB thickness series (Figure 6(b)). In Figure 6(c), the $J-V$ data of the LTB sample with $\sim 250 \mathrm{~nm}$ thick $\mathrm{ZnO}: \mathrm{Al}$, the HTB sample with $\sim 430 \mathrm{~nm}$ thick $\mathrm{ZnO}$ :Al, and the reference sample are compared to clearly demonstrate their different behaviour.

To further elucidate the two-region $J-V$ behaviour and the effect of thermal budget, plots of the ideality factor, $n$, as a function of $V$ were made (Figure 6(d)). The ideality factor is calculated from the gradients of $\ln \left(J_{D}\right)-V$ plots and since this gradient is not constant, neither is $n$. We note that this method of calculating $n$ does not account for the parasitic resistances and so the extracted $n$ values are out of the normal range $(1<n<2)$, but, importantly, they serve as a measure of the degree of nonideality at various biases (further note that larger $n$ values can also be due to excessive recombination). For the reference and the LTB samples, $n$ increases with $V$ and reaches a maximum in the leakage current dominated region (region 1) and then decreases and reaches a local minimum in the diode current dominated region (region 2). However, for the HTB sample, the recovery to lower $n$ values at high bias is not observed, which again indicates that the leakage current dominates throughout. Figure 6(d) also includes the expected ideal diode response of the reference cell, that is, with zero leakage current (plotted using the lowest $n$ value in the bias range). Any shift from this ideal response to higher current values in region 1 is attributed to the contribution of the leakage current, as was seen for all devices.

Evidently, the degradation of the cell performance upon exposure of the samples to an increasing thermal budget is to be attributed to a significant increase in the leakage current (decrease in $R_{\mathrm{sh}}$ ) and a consequent reduction of FF, $V_{\mathrm{oc}}$, and even $J_{\text {sc }}$. Because a leakage current is already present in the reference cell, we infer that the mechanisms of shunting are most certainly related to pinholes in the CIGS layer that 
are caused by unwanted $\mathrm{CuSe}_{x}$ secondary-phase formation during CIGS evaporation.

\section{Conclusions}

In summary, aluminium-doped zinc oxide layers for CIGS solar cells were deposited under LTB and HTB conditions by the ETP-CVD technique. $\mathrm{ZnO}$ :Al layers grown at $\mathrm{HTB}$ have better electrical properties compared to $\mathrm{ZnO}$ :Al layers grown at LTB. However, higher solar cell efficiencies were obtained when using LTB conditions ( $11 \%$ for a $\mathrm{ZnO}: \mathrm{Al}$ thickness of $\sim 125 \mathrm{~nm}$ ) than when using HTB conditions ( $9 \%$ for a $\mathrm{ZnO}: \mathrm{Al}$ thickness of $\sim 100 \mathrm{~nm}$ ). Device efficiency was primarily limited by low shunt resistances; this was attributed to pinholes in the CIGS layer, whose detrimental effect on efficiency was enhanced upon use of high thermal budget $\mathrm{ZnO}: \mathrm{Al}$ deposition. The thermal enhancement of shunt currents through macroscale defects (pinholes) was deemed to be a more significant factor than the previously reported effect of chemical migration, and this points out that the processing restrictions for transparent conducting oxide (TCO) deposition in CIGS solar cell development are defined by the structural integrity of the active layers onto which the TCOs are grown.

\section{Conflict of Interests}

The authors declare that there is no conflict of interests regarding the publication of this paper.

\section{Acknowledgments}

The authors acknowledge M. J. F. van de Sande, W. Keuning, J. J. L. M. Meulendijks, and J. J. A. Zeebregts for their technical support. This work was financially supported by Interreg Vlaanderen Nederland, Solar Flare under Project no. IVAVLANED-1.59. The authors thank, also for the financial support, the Ministry of Economic Affairs, Pieken in de Delta Zuid-Oost (project CIGSelf Verbeteren). The research of M. Creatore has been funded by the Netherlands Organization for Scientific Research (NWO, Aspasia programma).

\section{References}

[1] M. A. Green, K. Emery, Y. Hishikawa, W. Warta, and E. D. Dunlop, "Solar cell efficiency tables (version 43)," Progress in Photovoltaics: Research and Applications, vol. 22, no. 1, pp. 1-9, 2014.

[2] N. G. Renganathan, M. V. Subramanian, and S. Mohan, "Electrodeposition route tosynthesize cigs films-aneconomical way to harness solarenergy," International Journal of Engineering Science and Technology, vol. 3, no. 1, pp. 206-212, 2011.

[3] K. Shoori and G. Kavei, “'Copper Indium Gallium DiSelenideCIGS Photovoltiac Solar Cell Technology” A review," International Materials Physics Journal, vol. 1, p. 15, 2013.

[4] M. Jean, Spectrally Resolved Current Losses in Cu (In, Ga)Se Thin-Film Solar Cells, Freie Universität Berlin, Berlin, Germany, 2008.
[5] U. Malm, Modelling and degradation characteristics of thin-film CIGS solar cells [Ph.D. thesis], Acta Universitatis Upsaliensis, 2008.

[6] U. Rau and M. Schmidt, "Electronic properties of $\mathrm{ZnO} / \mathrm{CdS} /$ $\mathrm{Cu}(\mathrm{In}, \mathrm{Ga}) \mathrm{Se}_{2}$ solar cells-aspects of heterojunction formation," Thin Solid Films, vol. 387, no. 1-2, pp. 141-146, 2001.

[7] S. Ishizuka, K. Sakurai, A. Yamada et al., "Fabrication of widegap $\mathrm{Cu}\left(\mathrm{In}_{1-x} \mathrm{Ga}_{x}\right) \mathrm{Se}_{2}$ thin film solar cells: a study on the correlation of cell performance with highly resistive i- $\mathrm{ZnO}$ layer thickness," Solar Energy Materials and Solar Cells, vol. 87, no. 1-4, pp. 541-548, 2005.

[8] K. Sols, Simulation of Solar Cell Losses Depending on Cell Design, Chalmers Uiniversity of Technology, 2010.

[9] I. Repins, M. A. Contreras, B. Egaas et al., "19.9\%-efficient $\mathrm{ZnO} / \mathrm{CdS} / \mathrm{CuInGaSe} \mathrm{S}_{2}$ solar cell with $81.2 \%$ fill factor," Progress in Photovoltaics: Research and Applications, vol. 16, no. 3, pp. 235-239, 2008.

[10] K. Ramanathan, J. Keane, R. Noufi, and L. B. Vista, "Proceedings of the 31st IEEE Photovoltaics Specialists Conference and Exhibition," 2005.

[11] I. Volintiru, M. Creatore, B. J. Kniknie, C. I. M. A. Spee, and M. C. M. van de Sanden, "Evolution of the electrical and structural properties during the growth of $\mathrm{Al}$ doped $\mathrm{ZnO}$ films by remote plasma-enhanced metalorganic chemical vapor deposition," Journal of Applied Physics, vol. 102, no. 4, Article ID 043709, 2007.

[12] M. V. Ponomarev, M. A. Verheijen, W. Keuning, M. C. M. van de Sanden, and M. Creatore, "Controlling the resistivity gradient in aluminum-doped zinc oxide grown by plasma-enhanced chemical vapor deposition," Journal of Applied Physics, vol. 112, Article ID 043708, 2012.

[13] B. Hoex, A. J. M. van Erven, R. C. M. Bosch et al., "Industrial high-rate $(\sim 5 \mathrm{~nm} / \mathrm{s})$ deposited silicon nitride yielding high-quality bulk and surface passivation under optimum anti-reflection coating conditions," Progress in Photovoltaics Research and Applications, vol. 13, no. 8, pp. 705-712, 2005.

[14] K. Sharma, A. Chandramohan, B. Macco, B. L. Williams, H. C. M. Knoops, and M. Creatore, To be submitt, 2014.

[15] S. Kijima and T. Nakada, "High-temperature degradation mechanism of $\mathrm{Cu}(\mathrm{In}, \mathrm{Ga}) \mathrm{Se}_{2}$-based thin film solar cells," Applied Physics Express, vol. 1, no. 7, Article ID 075002, 2008.

[16] R. Groenen, J. L. Linden, H. R. M. Van Lierop, D. C. Schram, A. D. Kuypers, and M. C. M. Van De Sanden, "Expanding thermal plasma for deposition of surface textured $\mathrm{ZnO}$ :Al with focus on thin film solar cell applications," Applied Surface Science, vol. 173, no. 1-2, pp. 40-43, 2001.

[17] R. Groenen, J. Löffler, P. Sommeling et al., "Surface textured $\mathrm{ZnO}$ films for thin film solar cell applications by expanding thermal plasma CVD," Thin Solid Films, vol. 392, no. 2, pp. 226230, 2001.

[18] D. C. Schram and G. M. W. Kroesen, U.S. Patent no. 4,871,580, 1989.

[19] European Patent No. 0297637, 1992.

[20] M. V. Ponomarev, M. A. Verheijen, W. Keuning, M. C. M. van de Sanden, and M. Creatore, "Controlling the resistivity gradient in aluminum-doped zinc oxide grown by plasma-enhanced chemical vapor deposition," Journal of Applied Physics, vol. 112, Article ID 043708, 2012.

[21] M. C. M. van de Sanden, R. J. Severens, W. M. M. Kessels, R. F. G. Meulenbroeks, and D. C. Schram, "Plasma chemistry aspects of a-Si:H deposition using an expanding thermal plasma," Journal of Applied Physics, vol. 84, no. 5, pp. 2426-2435, 1998. 
[22] M. Creatore, Y. Barrell, J. Benedikt, and M. C. M. Van De Sanden, "On the hexamethyldisiloxane dissociation paths in a remote Ar-fed expanding thermal plasma," Plasma Sources Science and Technology, vol. 15, no. 3, pp. 421-431, 2006.

[23] H. C. M. Knoops, S. Smit, B. W. H. van de Loo et al., Submitted to Journal of Vacuum Science \& Technology A.

[24] A. Chirilă, S. Buecheler, F. Pianezzi et al., "Highly efficient $\mathrm{Cu}(\mathrm{In}, \mathrm{Ga}) \mathrm{Se} 2$ solar cells grown on flexible polymer films," Nature Materials, vol. 10, no. 11, pp. 857-861, 2011.

[25] S. Dongaonkar, J. D. Servaites, G. M. Ford et al., "Universality of non-Ohmic shunt leakage in thin-film solar cells," Journal of Applied Physics, vol. 108, no. 12, Article ID 124509, 2010. 

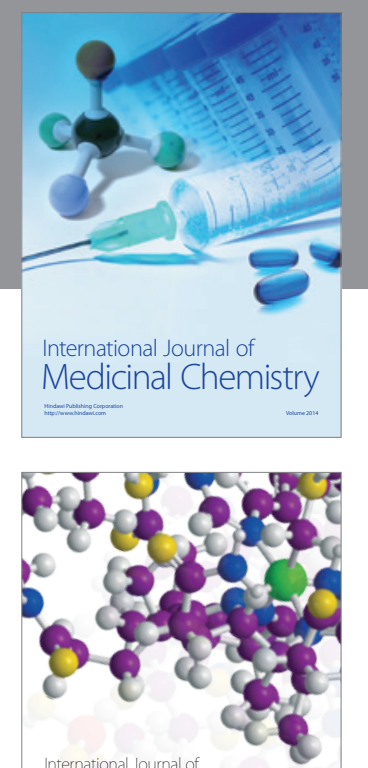

\section{Carbohydrate} Chemistry

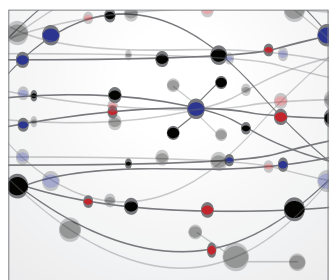

The Scientific World Journal
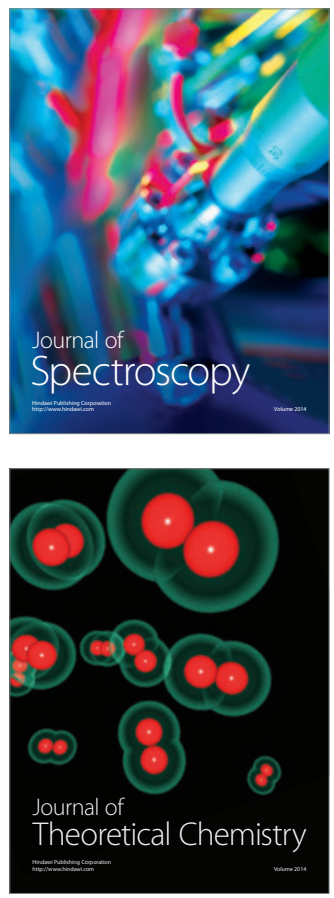
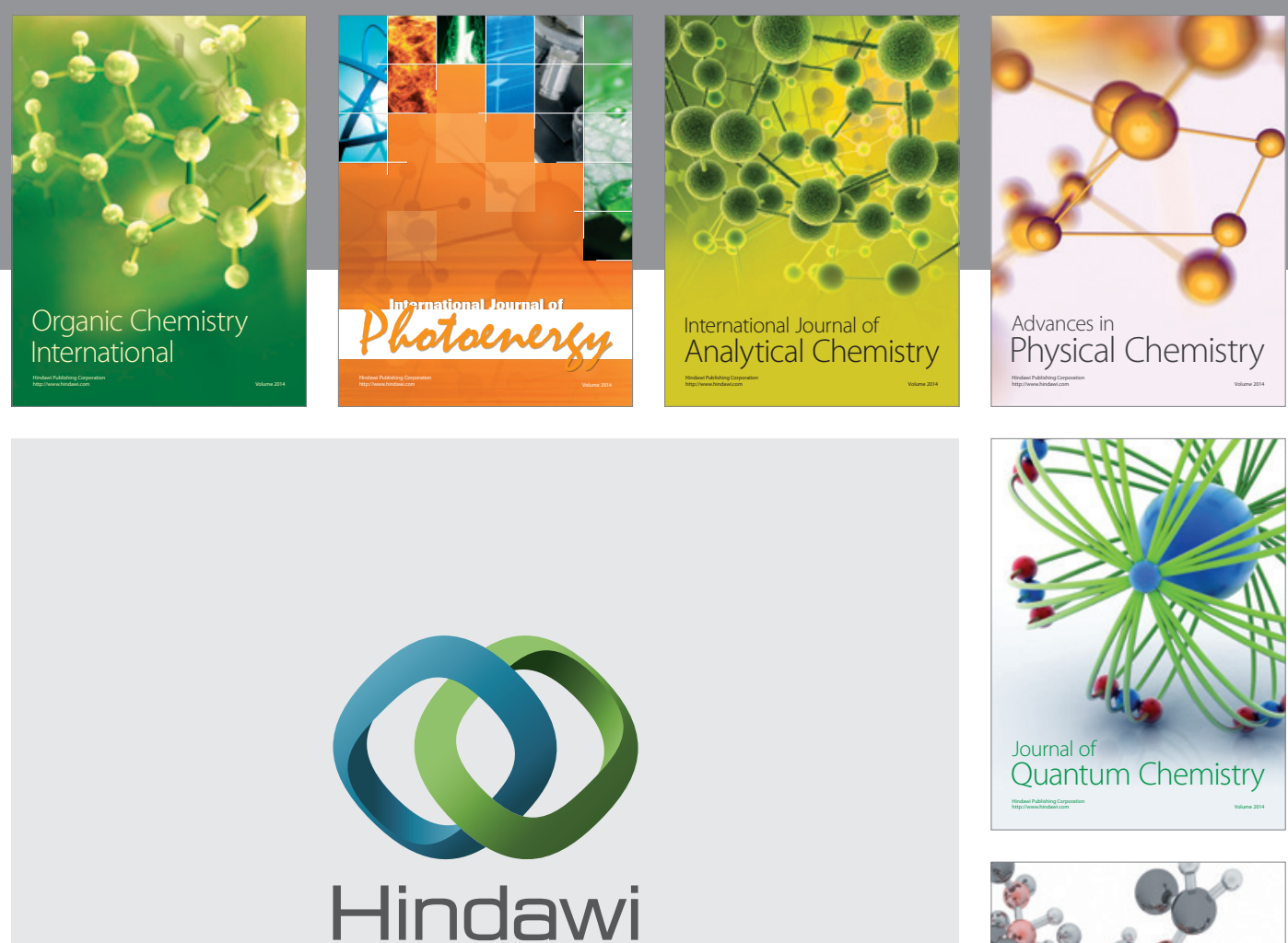

Submit your manuscripts at

http://www.hindawi.com

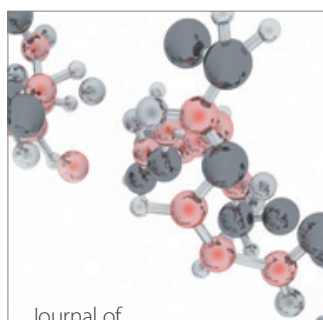

Analytical Methods

in Chemistry

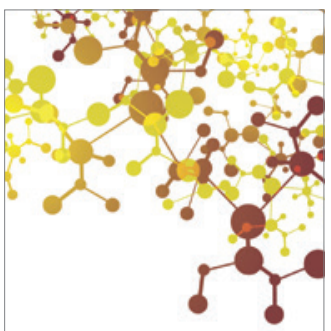

Journal of

Applied Chemistry

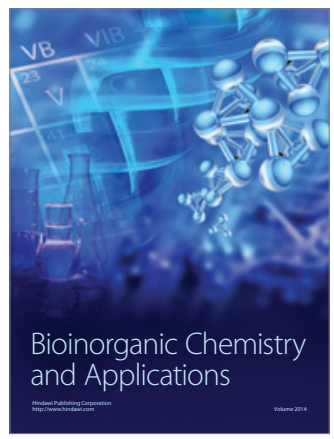

Inorganic Chemistry
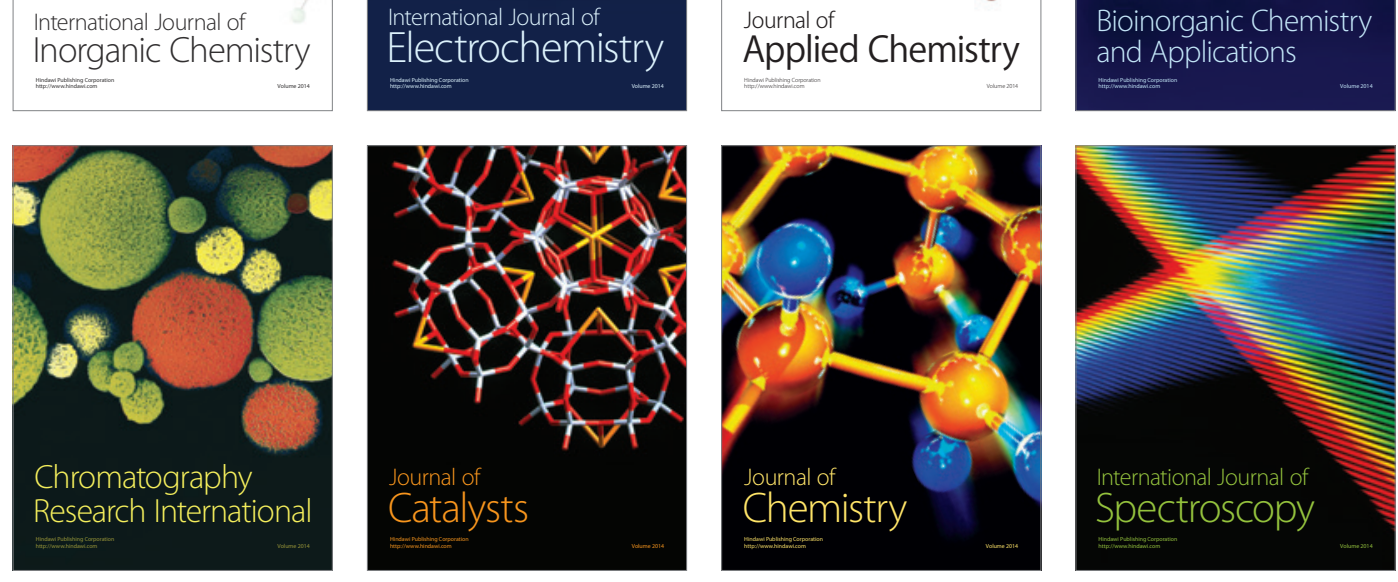